\title{
BASIS OF THEORETICAL DETERMINATION OF ARMED CONFLICT
}

\author{
Ivan Petrović \\ University of Defence, Belgrade \\ Saša Antanasijević \\ Air Force and Air Defence Training Centre, Republic of Serbia \\ Milan Kankaraš \\ Ministry of Defense of the Republic of Serbia
}

\begin{abstract}
This paper presents the theoretical basis of the origin and development of thoughts of armed conflict. The historical-comparative method, content analysis and the methods of definition and classification have been primarily applied in the paper. In addition to the introduction and conclusion, the paper consists of two more parts. The emergence of civilization thought about the notion of war and armed conflict is described in the first part. Furthermore, the first part relates to the perception of armed conflict in accordance with classic and military theories including modern theories of warfare. Classification of armed conflicts is described in the second part.
\end{abstract}

Key Words: armed conflict, the Geneva Conventions, war

\section{Introduction}

\begin{abstract}
$\Delta$ rmed conflicts have evolved along with the development of the society, science and technology. The purpose of the study of this phenomenon is to try to define and construct defence mechanisms and reactions of the society to the potential emergence of armed conflicts. How to regulate the society in the sense of the defence, how to know and predict the course of events and to timely respond to such phenomena are the questions and issues faced by a lot of societies nowadays. The study of armed conflict in the 21 stcentury is particularly complicated by the increased frequency of conflicts at the global level, andalso simplified with the development of thoughts of the collective security as the only possible response to threats. However, it is always necessary to look at the roots of armed conflict and sometimes look for theories that several centuries ago established the basis of something that is now called the modern war.
\end{abstract}

\section{Notional Determination of Armed Conflict}

The term armed conflict finds its place in the international dictionary for the first time in 1946 during the Conference of the National Red Cross, when it was proposed that solutions to all armed conflicts, whether interstate or within one country, are subjected to 
a single corpus of international treaty law (Elder, 1979). Although this initiative has not been accepted until nowadays, the concept of armed conflict survived and kept its value in the domain of international war and humanitarian law. The reason for this is its acceptance in all most important treaties in this field.

\section{The notional determination of Armed Conflict according to the Geneva Convention}

According to the documents of international humanitarian law, there are legally defined standards governing all aspects of warfare. These standards are established in the four Geneva Conventions of 1949, which are the primary sources of international humanitarian law. These conventions have been ratified by almost all countries all over the world and they contain a set of binding restrictions that determine behavior in war.

In the field of contract law, the notion of armed conflict was established for the first time in the Geneva Conventions, which stipulate that they are applied in the case of "published or of any other armed conflict which may arise between two or more parties, even if one of them did not recognize state of war". The term armed conflict is also mentioned in Common Article 3 of the four Geneva Conventions, which applies to "the case of armed conflict which has not an international character and arises in the territory of one of the high contracting parties" (Elder, 1979).

In comments to the Geneva Conventions (hereinafter: comments) there is a concept that has been compared to the traditional concept of war, which is more comprehensive and corresponds better to reality. In the case of international armed conflicts comments stand out: "Any disagreement arising between two countries and which leads to the intervention of armed forces is an armed conflict in accordance with meaning of Article 2 of the Convention" (Geneva, 1960).

However, when it comes to the concept of armed conflict, which does not have an international character, according to the Commentaries: "In general, it must be recognized that the conflicts referred to in Article 3 are armed conflicts, in which both parties participate in hostilities - in short, conflicts that are very similar to the international war, but take place within a state" (Geneva, 1960). Taking into consideration the aforementioned, it can be concluded that the use of armed forces was an essential element for defining both international and non-international armed conflicts. Another important element of this concept is the requirement that the armed forces really, actually take part in hostilities.

Despite the aforementioned, it is necessary to recall that the Doctrine of international humanitarian law recognizes more demanding definitions of armed conflict. One of them is as follows "the use of weapons as an instrument to harm persons and/or property in order to overcome the opposing party" (Geneva, 1960).

Bearing in mind the aforementioned, it is obvious that the lowest common factor of armed conflict is the engagement of the armed forces. If there is intervention of the armed forces, regardless of the vision in which this intervention is manifested, it is the international armed conflict. The conflict that does not have the international character is a situation where there has been enmity between the armed forces (at least one of them is non-state entity), which takes place within the territory of one state. 
There are other ways of determination of armed conflict. For example, the armed conflict between two countries includes the involvement of military forces on both sides and at least 1,000 dead as a result of military activities (Radivojević, 2013), or armed conflict is a result of the incompatibility that concerns government or territory, where two sides are engaged (one of them is mandatory state) and where the ultimate outcome is of at least 25 dead as a result of military activities (Wallensteen 2012).

\section{The notional determination of Armed Conflict in Military Sciences}

According to the Doctrine of operations, armed conflicts represent a process of mutual destruction of conflicting parties (Doktrina operacija Vojske Srbije, 2012). Armed conflicts are characterized by the application of the armed forces to achieve limited objectives. Conflicts can be carried out between states or within national borders, in the form of armed rebellion or the fight against terrorism in an urban or uninhabited area (Doktrina Vojske Srbije, 2010).

Armed conflict exists if foreign armed forces, armed groups, conflicting fractions or terrorist forces use force or threat of force to promote their own interests or objectives. Moreover, conflicting parties apply the best possible combination of political instruments including diplomatic, economic and psychological resources and means.

The most extreme or ultimate form of armed conflict can take the form of war. The characteristic difference between armed conflict and war lies in the fact that the significant part of population of the conflicting parties is mobilized. Another difference lies in the fact that in case of war the conflicting parties are considered to be so serious threats to their own objectives and interests that they believe there is no other way, but to use substantial military force, usually over a long period of time. The state of war would certainly exist if a country's own military forces attacked the integrity of other countries.

The notion of armed conflict can be defined in the narrow and broad sense. Armed conflicts in the narrow sense mean the use of the armed forces by one or more states against another state or group of states with a view to imposing their own will to them attacked countries (Sakan, 2003).

In a broader sense, armed conflict means any use of the armed forces, whether it comes to the engagement of one state or group of states against another state or group of states with a view to imposing their own will, or that it is an internal conflict (rebellion or revolution) or border incidents in which a firearm is used and the armed forces deployed (Sakan, 2003).

Armed conflict is the basic form of objective reality, which manifests the engagement of all capacity of military forces. The traditional armed conflicts, which have historically been mostly symmetrical, have received a completely new dimension in recent decades. The symmetry, in terms of military power, economic, political and diplomatic influence of conflicting parties, has disappeared in recent decades and armed conflicts have become bisymmetrical. The emergence of bisymmetrical armed conflicts constitutes an appropriate impulse for finding new strategy of performing armed conflict with an inferior side in the conflict. As a result of the aforementioned, in the last two decades, armed conflicts have become asymmetric, in which it is possible to achieve important effects, sometimes of strategic proportions, with the help of the surprise factor and the initial planning and with a relatively small 
forces. At the end of last and the beginning of this century armed conflicts, in which air forces have the main role in achieving strategic objectives, respectively, air defence forces (depending on goals and strategic possibilities of conflicting parties), are bisymmetrical according to their characteristics (Petrović, Kankaraš and Cvetković, 2016). After completion of main operations, these armed conflicts often take the form of asymmetric conflicts.

The acceptable definition of armed conflict is that it represents the military - technological social phenomenon (genus proximum - senior notion in relation to the term that is defined), in which the mutual destruction of two or more adversaries in the conflict fulfill political, economic, military, diplomatic or confessional objectives of the conflicting adversaries, which could not be achieved by other activities (diferencia specifica - the notion of specific differences, which is defined in relation to all other terms included in the senior notion) (Petrović, Cvetković and Stojiljković, 2015).

\section{Classification of Armed Conflicts}

The classic law of war knew only the concept of war between sovereign states.

However, the warfare within the country, such as rebellion or revolution was not considered to be the war in terms of international law, but civil war according to the applicable national law (Abi-Saab, 1991).

The traditional concept of inter-state war was based on formal and subjective criteria of a unilateral declaration by the sovereign in the form of a declaration of war or ultimatum. This criterion for determining the beginning of implementation of the law of war proved to be, like many others, insufficiently precise.

State practice between the world wars has confirmed that armed conflicts begin without a formal announcement, which can be an argument of one or more conflicting parties to eliminate the application of the law of war (Berman, 2004).

However, only the tragic experiences of the Second World War will have a serious impact on the formal concept of inter-state war to expand the concept of international armed conflict.

\section{International Armed Conflicts}

The introduction of the notion of international armed conflict, which includes the war, according to the Geneva Convention is based on factual, objective and functional criteria. The result of that is the common Article 2, which stipulates that the Geneva Convention should apply in every armed conflict, which may arise between contracting states, whether they publish war or not. Moreover, the Geneva Conventions apply to all cases of partial or total occupation of the territory of a contracting party, even if the mentioned occupation meets with no military resistance.

Moving from the formal and subjective to factual and objective criteria had a significant impact on the change of the concept of interstate war. At first, the declaration of war is no longer a necessary condition for the existence of a state of war and the application of the rules of international law. The Geneva Conventions certainly do not forbid the dec- 
laration of war or any other statement of state, but they stop connecting declaration of war with legal consequences. The consequence is that the declaration of war becomes legally irrelevant because the international armed conflict represents the fact on the field (Dinh, 2002). The recognition of war has been made irrelevant by insisting on factual criteria. The Geneva Convention expressly regulates the situation when one of the participants in armed conflict does not recognize the existence of state of war.

Therefore, international armed conflict assumes disagreement, which arises between states and leads to the intervention of the armed forces, even if one party denies the existence of state of war (Geneva, 1960). Thus, it can be concluded that the existence of war or any other armed conflict represents de facto occurrence of hostilities.

How long the conflict lasted, how many people were killed and how many forces participated is not relevant for the existence of international armed conflict. . International humanitarian law does not determine the level and intensity of violence that armed operations must reach to the applicable rules related to international armed conflicts. It is enough to establish the authority over other conflicting side that is considered to be protected in terms of the Geneva Conventions by the armed forces of one state. Even if there was no warfare, the fact that the persons protected by the Convention were deprived of liberty should be sufficient for its implementation (Geneva, 1960).

The establishment of Protocol I had a significant influence on the development of the notion of international armed conflict. Therefore, this act revised the concept of international armed conflict by introducing a new category, which encompasses the national liberation and anti-colonial wars. Namely, according to this act, the international conflicts are performed in the territory of one state. The objective of one conflicting side is to achieve the right to self-determination. This kind of conflict was considered as an internal problem by the traditional laws of war. According to Paragraph 4 of Article 1 of the Protocol, the international armed conflicts are classified as "armed conflicts in which people are fighting against colonial domination, foreign occupation and racist regimes, using the right of nations to self-determination, confirmed in the United Nations Charter and the Declaration on Principles of International Law concerning friendly relations and cooperation between states in accordance with the Charter" (Izvori medjunarodnog humanitarnog prava, 2007).

The analysis of this provision indicates the existence of several basic criteria required for the conflict that takes place in the territory of a state to be qualified as international armed conflict. First of them is the existence of armed conflict, respectively the existence of the usual conditions required for the qualification of a certain situation as armed conflict (Sakan, 2003). The second criteria is the claim that it is a conflict when government forces oppose forces that belong to the people who have still not exercised their right to selfdetermination by means of weapons, fighting against colonial domination, foreign occupation and racist regimes. The third condition to perform equalization of international conflict is a statement of government that represents the people engaged against contracting state to apply the Geneva Conventions and this Protocol in relation to that conflict. In this regard and it is also the fourth condition, it is necessary that the state itself in whose territory the conflict takes place is a contracting party to the Geneva Conventions and Protocol.

It can be concluded that the ability of engagement in armed conflict will remain the last instrument of state power in the future. However, three factors dictate that the emergence of inter-state conflict will be probably reduced. Firstly, it is not likely that bipolar competition created between the global superpowers, as it was the case during the Cold War, will be re- 
peated. Secondly, the superiority of the most powerful states is likely to discourage strategic conventional attacks against them, their allies or those regions, where they have strategic interests. Thirdly, the risk that the protagonists will grow because of the cost and lethality of weapons spills over into regional and global stability and strengthens the international antiwar beliefs and punishments for the participants of the conflict. Despite the aforementioned, the wars will continue to occur and they will potentially be more dangerous due to the increased lethal effects, massive weapons systems and the growing impact of the conflict.

\section{Non-International Armed Conflicts}

Conflicts within the state, even when they are characterized by durability, organization and high level of violence, were regulated only by the internal law of the state in whose territory they took place, ${ }^{1}$ not internationally until the end of the Second World War, but However, during the first decades of 20thcentury the first indications of the establishment of different views on the relationship of international law of war and wars within states appeared. Due to the civil war in Spain in 1938 the Assembly of Nations adopted a resolution on the protection of civilians from aerial bombardment, omitting the distinction between interstate wars and wars within the country (League of Nations, 1938).

Despite these and other efforts for civil wars to undergo some principles of international humanitarian law, none of the existing international agreements, including all of the Hague Convention, could not deal with this kind of war. States feared that their possible inclusion in the field of application of the rules of international law of war would mean unlawful interference in their sovereignty and exclusive jurisdiction. Namely, only the horrors and destruction left behind by the Second World War would strengthen the belief that internal conflicts should be subject to the international laws of war.

Acting in this direction, the Geneva Conventions have made at that time a revolutionary step forward in the sphere of the internal jurisdiction of extending the application of the rules of the international protection of victims of the non-international conflict. The protection provided by Article 3 is common to the four Geneva Conventions (Izvori medjunarodnog humanitarnog prava, 2007). It is based on a request for humane procedures against persons taking no active part in hostilities, including members of the armed forces who have laid down their arms and persons unable to combat due to sickness, wounds, or any other cause, and without any discrimination.

Common Article 3 of the Geneva Convention has been declared a "Convention in miniature", "Convention of the Convention," which provides mandatory minimum standards of protection in all armed conflicts. In any case, it is difficult to argue that this article has several important virtues. In the first place, it is its clarity, simplicity and the possibility of applying the principles of humanity. This article has an additional advantage because it is automatically applied irrespective of the nature of the conflict in the territory of a state. Therefore, it can be said for its provisions that they represent the absolute minimum threshold for the entire application of international humanitarian law, and that deviation from them (in the negative sense) is not allowed in any armed conflict.

\footnotetext{
${ }^{1}$ Conflicts within the state can be called internal conflicts.
} 
Additional Protocol II has brought significant changes when it comes to the concept of the non-international armed conflict, which has become the dominant form of conflict in the meantime. For the first time, this document has precisely formulated material elements, whose presence qualifies a particular situation as the non-international conflict in which the new, higher standards of protection of victims is applied. This led to the adoption of a new notion, and therefore to redundancy of protection regime in relation to Article 3 of the Geneva Conventions.

Taking into consideration the aforementioned, it can be concluded that there are four basic conditions for the categorization of non-international armed conflicts, which are the criteria for its application, namely:

a) that conflict takes place in the territory of the contracting party between its armed forces and rebel forces or other organized armed groups;

b) that rebel forces have responsive command;

v) rebel forces exercise control over part of its territory, which allows them to carry out sustained and concerted operations; and

g) rebel forces exercise such control that allows them to implement Protocol II (Commentary 1987).

If the abovementioned is achieved then the Protocol introduces a distinction between non-international armed conflicts to be regulated and whose existence requires stronger intensity and conflicts in common Article 3 of the Geneva Conventions, which assume lower or weaker intensity. It also leads to the duplication of the regime of protection of victims of non-international armed conflicts.

The next step towards the complexity of the concept of non-international armed conflict was the adoption of the Rome Statute, which, as it was mentioned, introduced the category of non-international armed conflicts, which are characterized by the continued violence.

It is actually about the armed conflicts in Article 8, Paragraph 2, Point $d$ of the Statute "taking place in the territory of a state when there is continued armed conflict between the government authorities and the organized armed groups or between such groups." As a new category, these types of conflicts are somewhere between non-international armed conflict of Article 3 of the Geneva Conventions and conflicts covered by Protocol II. According to the criteria of intensity, conflicts characterized by continued violence appear on the scale as a middleweight, and in addition to Article 3 Protocol II could apply to them(Knežević 2007).

When it comes to internal conflict, it is very likely that in the future this kind of conflict will become more frequent. Internal conflicts would get international characteristics if some of the conflicting parties gained the support of influential global centers of power.

\section{Conclusion}

Definition and classification of armed conflict is a problem that is as old as the theoretical systematized knowledge of it. Taking into consideration that the sphere of objective reality called armed conflict exists as a social and technological phenomenon determined by the development of civilization, it is necessary to define armed conflict at an appropriate scientific level (Petrović, Cvetković and Stojiljković, 2015). Only this approach will provide better understanding of armed conflict and specific forms of its manifestation from the scientific point of view. 


\section{References}

[1] Abi-Saab, R. Humanitarian law and internal conflicts: the evolution of legal concern. Dodrecht: Martinus Nijhoff Publishers, 1991.

[2] Berman, N. Privileging Combat? Contemporary conflict and the legal construction of war. Columbia Journal of Transnational Law, 2004.

[3] "Commentary on the Aditional protocols of 8 june 1977 to the Geneva conventions of 12 august 1949." 1987.

[4] Dinh, N. Q. Droit international public. Paris: Librairie générale de droit et de jurisprudence, 2002.

[5] "Doktrina operacija Vojske Srbije." Beograd, 2012.

[6] "Doktrina Vojske Srbije." Beograd, 2010.

[7] Elder, D.A. "The historical background of common article 3 of Geneva conventions of 1949." Journal of international law 37 (1979).

[8] Geneva, Convention. "Commentary III Geneva Convention relative to the treatment of prisoners of war." 1960.

[] "Izvori medjunarodnog humanitarnog prava." Beograd, 2007.

[10] Knežević, Predić. Ogled o međunarodnom humanitarnom pravu: izvori, domen primene, subjekti. Beograd: Fakultet političkih nauka, 2007.

[11] League of Nations, Official journal, Special Supplement 183, 1938.

[12] Petrović, Ivan, Krum Cvetković, and Zoran Stojijković. "Teorijsko određenje vazduhoplovnih i protivvazduhoplovnih dejstava [Theoretical Determination of Air Operations and Anti-Air Operations]." Vojno delo (Media centar) 67 (4), ISSN 042-8426, UDK 355/359 (2015).

[13] Petrović, Ivan, Milan Kankaraš, and Krum Cvetković. "Scientific Development of Notional Determination of Basic Terms of Defence Science." Vojno delo (Media centar) 8, ISSN 0042-8426, UDK 355/359 (2016).

[14] Radivojević, Z. "Prag primene međunarodnog humanitarnog prava." Pregledni rad (Pravni fakultet), 2013.

[15] Sakan, Momčilo. Vojne nauke. Beograd: VIZ, 2003.

[16] Wallensteen, Peter. Understanding Conflict Resolution: War, Peace and Global System. 3. London: Sage Publications, 2012. 